\title{
In vitro biological activity of the Croton blanchetianus (Baill) essential oil against Rhipicephalus (Boophilus) microplus (Acari: Ixodidae)
}

\author{
Onaldo Guedes Rodrigues*, Brunna Rodrigues Muniz Falcão, Beatriz Correa Barbosa, Andreia Vieira Pereira, Vitoria \\ Viviane Ferreira de Aquino
}

Master's Program in Animal Science, Universidade Federal de Campina Grande, Academic Unit of Biological Sciences, Campus de Patos, Paraíba, Brazil

\section{ARTICLE INFO}

Article history:

Received on: November 12, 2017

Accepted on: January 23, 2018

Available online: January 31, 2019

Key words:

Phytochemistry,

Ethnoveterinary, Semiarid,

Cattle tick, Biotechnology

\section{ABSTRACT}

Brazil numerous plant species are used for controlling ectoparasites on cattle. However, the need to consolidate this popular knowledge through existing chemical characterization of secondary compounds in these plants and the application of bioassays able to reveal its biological action observed. For this study, we obtained the essential oil of the Croton blanchetianus by hydrodistillation and their chemical compounds identified by gas chromatography coupled with mass spectrometry. The major chemical constituents stood out as eucalyptol (16.9\%), $\beta$-caryophyllene (15.9\%), and germacrene-D (14.5\%). Various concentrations of the C. blanchetianus essential oil were used in order to test their biological action on the cattle tick Rhipicephalus (Boophilus) microplus. There was a significant acaricide efficacy, and the results were statistically significant at a confidence level of $95 \%$.

\section{INTRODUCTION}

The cattle tick Rhipicephalus (Boophilus) microplus is one of the main responsible for economic losses to production in tropical and subtropical countries. Different forms of control, separate, or associated have been proposed, and research directed toward finding alternatives in tick control is diverse [1].

Historically, the method further explored against the cattle tick has been the traditional administration of chemical compounds, based on the use of active principles that act in various life stages of the parasite and its vectors. The indiscriminate use of acaricide compounds has, however, culminated in the appearance of populations of $R$. (Boophilus) microplus resistant to these products, generating large expenses due to ineffective treatments [2].

The use and efficacy of medicinal plants are assigned to popular observations that contribute significantly to the therapeutic virtues' dissemination that has been accumulated through the years [3], fueling the interest around the investigation of chemical substances with pharmacological action, such as coumarin, flavonoids, terpenoids, alkaloids, and tannins. In this sense, the most recent research involves the plant extracts and essential oils' screening to know the secondary metabolites with relevant biological acaricide activities [4].

\footnotetext{
*Corresponding Author

Onaldo Guedes Rodrigues, Universidade Federal de Campina Grande.

Email: onaldo@cstr.ufcg.edu.br
}

The Euphorbiaceae family comprises one of the largest families of angiosperms, covering about 7500 species, represented by 300 plants. Between the Euphorbiaceae families with potential pharmacological use, stands out Croton by its large number of species (1200) distributed in all tropical and subtropical regions. With around 300 species, Brazil is one of the main centers of diversity of the genus, which was represented in various environments and vegetation types (Berry et al. 2005). Among the species of Croton with strong economic and therapeutic potential due to the essential oils' presence, we have Croton blanchetianus, a native plant of Northeast and popularly known as "Marmeleiro Preto (popular name)," occurring in vegetation "Carrasco" (type of soil found to Ceará state) and "Caatinga biome" [5].

Therefore, C. blanchetianus has been dedicated to the study of the main tick species that compromises the productivity of cattle ranching; $R$. (Boophilus) microplus, a hematophagous ectoparasite originating in Asia, that is commonly found in regions of tropical and subtropical climates (74\% of Latin America) and around $96 \%$ of Brazilian municipalities. About $80 \%$ of the world cattle population is affected by tick infestation [6]. Depending on the region's climatic conditions, it can cause great damage in Brazilian cattle assuming a role of fundamental importance, because this parasite ranks highest in damaging animal performance as result of predatory actions, mechanical and toxic effects [7].

In Brazil, the economic losses caused by infestation by ticks are on the order of $40 \%$, affecting milk production, $27 \%$ by mortality, $11 \%$ on the 
reproductive performance, $9 \%$ in expenses with acaricides, $5 \%$ by the reduction in weight gain, $5 \%$ in bank interest, $3 \%$ for poor quality of leather, and expenses in control and prevention of hemoparasitoses [8]. The decrease in the by-products' quality such as leather is one of the significant losses caused by this parasite [9]. With the current difficulties in the cattle tick's control and its ills with traditional methods, the search for alternative treatments becomes increasingly important, among which stands out the plant's use in the control of tick infestations be it with the use of extracts, teas, and oils of various plant species [4]. These plants have substances with different chemical structures with activity against arthropods. Therefore, we hypothesize that $C$. blanchetianus will possibly be an important alternative to tick control and may reduce economic impacts and cause less damage to the ecosystems, compared to the use of synthetic pesticides [10].

Brazil has approximately 55,000 species of plants, considered the country with the greatest biodiversity on the planet. Despite the title, there are few studies on the therapeutic effect and acaricide efficacy of many of these species [6]. The search for easier to use, less expensive products with the increased resistance of parasites to allopathic products has, in recent years, encouraged this alternative for the control of ectoparasites [11]. According to Fernandez [12], it was seen that the use of isolated plant extracts or associates might be causing a slower development of resistance in addition to decreasing the residual effect in animal products. In several countries, research has been conducted using plant extracts for the control of tick [13].

In Brazil, a diversity of plants has medicinal use, among which stands out C. blanchetianus (Baill). species exclusively Brazilian (found in the states of Alagoas, Bahia, Ceará, Minas Gerais, Paraíba, Pernambuco, Piauí, Rio Grande do Norte, and Sergipe), occurring in vegetation "Carrasco" and "Caatinga" biome [5]. Thus, the main objective of this research was to chemically characterize the plant originating in "Caatinga" and evaluate their pharmacological efficacy in parallel with in vitro bioassays against the cattle tick.

\section{MATERIALS AND METHODS}

\subsection{Collection and Identification of Plant Material}

The C. blanchetianus leaves were collected in March 2014 at the beginning of the day, on the São José do Bonfim - Patos-PB's county, between the geographic coordinates of latitude $07^{\circ} 08^{\prime} 20$ 9" and longitude $037^{\circ} 18^{\prime} 062^{\prime \prime}$. Then, a representative sample of the species for botanical identification and deposited in the Herbarium of the Federal University of Campina Grande, Patos -PB's county, with the number $\neq 496$, and the other part of the sample was forwarded to LAMPA (multi-user laboratory for environmental research) for pharmacological processing.

\subsection{Essential Oils' Extraction and Chemical Characterization}

The C. blanchetianus's essential oil from fresh leaves $(820.0 \mathrm{~g})$ was obtained by hydrodistillation, using Clevenger type apparatus. The extraction was done in an approximate period of $2 \mathrm{~h}$ [2]. Then, the oil was dried with anhydrous sodium sulfate to remove the excess of water and was placed in a clean container, amber colored, and kept in a refrigerator at a temperature of $0-4{ }^{\circ} \mathrm{C}$ until its use.

The essential oil chemical identification of $C$. blanchetianus's sheets components was obtained by gas chromatography coupled with mass spectrometry (GC/MS), on a Hewlett-Packard model 5971 spectrometer operating at $70 \mathrm{eV}$ ionization energy. We used a fused silica capillary column DB-5 $(30 \mathrm{~m} \times 0.25 \mathrm{~mm}$ id, $0.25 \mu \mathrm{m}$ film thickness) and helium carrier gas with a flow of $1 \mathrm{~mL} / \mathrm{min}$ split. The injector and detector temperatures were programmed to $250^{\circ} \mathrm{C}$ and $200^{\circ} \mathrm{C}$, respectively. The column temperature was programmed from $35^{\circ} \mathrm{C}$ to $180^{\circ} \mathrm{C}$ at $4^{\circ} \mathrm{C} / \mathrm{min}$ and then from $180^{\circ} \mathrm{C}$ to $280^{\circ} \mathrm{C}$ at $10^{\circ} \mathrm{C} /$ $\mathrm{min}$. Mass spectra were obtained from 30 to $450 \mathrm{~m} / \mathrm{z}$. The individual components were identified by matching their mass spectra, 70 $\mathrm{eV}$, with the database, using the library constructed through the spectrometer with two others, using retention indices as a preselection, as well as by the pattern fragmentation's visual comparison with those reported in the literature.

\subsection{Obtaining $\boldsymbol{R}$. (Boophilus) microplus' Females}

The $R$. (Boophilus) microplus engorged females were collected directly from the cattle's body naturally infested in agriculture and stockbreeding property in the city of Patos-PB. The ticks were placed in the plastic containers with air circulation, until reaching the laboratory (LAMPA), taking care of their physical integrity, and the shipping time. The ticks' sampling was done by taking care not to collect ticks samples in properties that have performed the flock's chemical treatment at least for $\leq 50$ days.

\subsection{Engorged Females' Inoculation}

The ticks collected were taken to the laboratory and inspected with a stereoscopic microscope for confirmation of their physical and morphological integrity. Then, the selected females were cleaned, passing them twice in distilled water, and then drying them on filter paper. After drying, they were divided into groups (GI, GII, GIII, and control group [CG]), with 10 ticks each group, in triplicate, and then, they were individually weighed on analytical balance.

The oil obtained was diluted at the assay's moment, into three distinct dilutions, each dilution representing a group: (GI) Solution 2\%; (GII) solution $1 \%$; and (GIII) solution $0.4 \%$. A CG with distilled water used. For each dilution freshly prepared, we used in each group ten engorged females; they stayed immersed in $10 \mathrm{~mL}$ of the solution, for 5 min. After this time, the engorged females were dried and placed on filter paper in Petri dishes, adhered with an adhesive strip, and then incubated under controlled conditions, with controlled temperature and humidity $\left( \pm 27^{\circ} \mathrm{C}\right.$ and $\left.\mathrm{RH}>80 \%\right)$. At the end of 21 days, the engorged females' mortality evaluation was made. The mites' eggs obtained were transferred to disposable syringes adapted and kept in an incubator with controlled temperature, humidity, and ventilation $\left( \pm 27^{\circ} \mathrm{C}\right.$ and $\left.\mathrm{RH}>80 \%\right)$. The ticks' eggs evaluation of hatchability was performed 14 days after starting treatment.

\subsection{Evaluated Parameters}

The parameters observed in the evaluation of the biological action of $C$. blanchetianus essential oil on the tick were the following: (a) The period of pre-laying - public-private partnership (PPP) (period between the female's fall day and the onset of egg laying); (b) weight of engorged females - PT (initial and final); (c) weight of the egg mass - PMO; and (d) percentage of mortality - PM. To calculate the reproductive efficiency and the product's effectiveness (EP).

Equation: Adapted [14].

$$
\mathrm{RE}=\frac{\text { Egg weight } \times \% \text { hatching } \times 20.000 *}{\text { Engorged females' weight }}
$$

Where: $\mathrm{EP}=(\mathrm{RE}$ control $-\mathrm{RE}$ treated $) \times 100$ 
*Constant that indicates the number of eggs present in $1 \mathrm{~g}$ of feces.

The groups' monitoring was done each 3 days, by observing the reproductive mass under a microscope, analyzing the possible changes individually on each engorged female.

\subsection{Statistical Analysis}

The experimental delineation was completely randomized with four treatments and three replications. The obtained data were subjected to the variance analysis with the use of statistical software PROC GLM of SAS (1999), and the obtained averages were compared by Turkey test at a significance level of $95 \%$ probability $(P<0.05)$.

\section{RESULTS}

\subsection{C. blanchetianus Chemical Constituents}

The essential oil obtained by hydrodistillation of the sheets submitted a $0.72 \%$ yield in relation to the fresh material's weight used. By analysis into GC-MS, it was possible to identify and quantify 17 chemical constituents [Table 1]. The identified compounds are eucalyptol (16.9\%) as the major compound followed by $\beta$-caryophyllene $(15.9 \%)$ and germacrene D (14.5\%). For $C$. blanchetianus, these constituents account for $79.4 \%$ with $39.2 \%$ of monoterpenes and $10.3 \%$ sesquiterpenes constituents. The major compounds were cedrol (28.4\%), eucalyptol (17.4\%), and $\alpha$-pinene $(10.5 \%)$.

Table 1: Profile of the chemical constituents identified in the essential oil from the leaves of $C$. blanchetianus

\begin{tabular}{lccc} 
Constituents & RI (\%) & Constituents & RI (\%) \\
$\alpha$-pinene & $939(10.5)$ & Germacrene D & - \\
ß-pinene & $980(3.0)$ & Bicyclogermacrene & - \\
Sabinene & - & $\delta$-cadinene & - \\
ß-myrcene & $991(1.5)$ & Spathulenol & $1576(2.8)$ \\
p-cymene & $1026(4.2)$ & Caryophyllene oxide & $1581(1.2)$ \\
Eucalyptol & $1033(17.4)$ & Viridiflorol & - \\
$\gamma$-terpinene & - & Cedrol & $1589(28.4)$ \\
Linalool & $1098(1.5)$ & Alloaromadendreno & $1458(1.2)$ \\
Bornila acetate & $0(1.3)$ & p-cimen-8-ol & $1189(1.3)$ \\
Terpinila acetate & - & Criptona & $1186(1.3)$ \\
$\alpha$-copaene & - & Monoterpenes & $0(39.2)$ \\
ß-caryophyllene & $1418(3.8)$ & Sesquiterpenes & $0(10.3)$ \\
$\alpha$-humulene & $1452(1.3)$ & & \\
Total of chemical constituents identified 79.4\% & \\
\hline
\end{tabular}

*Retention indices (Adams, 2007). C. blanchetianus: Croton blanchetianus

\subsection{Pharmacological Action of the $C$. blanchetianus' Essential Oil on the Tick}

The observed data for the "marmeleiro" [Table 2] showed that, for the pre-laying period (PPP), the G1 differed statistically $(P<0.05)$ from other groups including the CG, already the $\mathrm{G} 2$ and G3 groups did not differ statistically from the CG. For the laying period (PP), there was no statistical difference between the groups and the $\mathrm{CG}$.

Regarding the parameter rate of egg production, Group 3 received much lower value than the $\mathrm{CG}$, which differed statistically $(P<0.05)$, which may indicate that this concentration interfered in the production of eggs by gravid females, while for the Groups 1 and 2, showed no statistical difference compared to CG. The rate of the plant's efficiency (EPO) was statistically superior to the CG for the three treatments, and the ticks' group treated with "marmeleiro" at $2 \%$ was higher $(P<0.05)$.

The $C$. blanchetianus' essential oil originated in the "Caatinga" biome presents a variety of chemical compounds with a predominance of monoterpenes and sesquiterpenes. The plant's essential oil showed toxicity against $R$. (Boophilus) microplus cattle tick in important moments of their physiological cycle. It is possible that the studied species can contribute to the cattle tick's control.

\section{DISCUSSION}

This chemical composition is compatible with literature data for Croton species whose essential oil was characterized by the predominance of monoterpenes and sesquiterpenes as major components. Studies conducted by Silva et al. [15], with the essential oil extracted from the Croton's leaves identified the presence of $\alpha$-pinene, sabinene, linalool, bornila of acetate, $\beta$-caryophyllene, germacrene $\mathrm{D}, \delta$-cadinene, $\alpha$-humulene, bicyclogermacrene, spathulenol, and eucalyptol as major compounds, corroborating with the data reported by [16].

The cedrol constituents, alloaromadendrene and criptona present in the C. blanchetianus essential oil was identified only in this work, which may be related to the existence of this species' chemotypes found only in the "Caatinga" biome.

Currently, it is possible to compare with data found in literature, the major chemical profile of various Croton species. These data can be searched in the Web of Science and Scifinder's databases [17]. Studying the essential oil from leaves of Croton adenocalyx A. DC., found $\alpha$-pinene, $\beta$-pinene, $\beta$-caryophyllene, and $\gamma$-elemene. Already Lima et al. [3] studying the same species found $\alpha$-pinene, biciclogermacleno, $\beta$-cariofilebo, germacrene-D, and $\beta$-oineno [18] studying the Croton bogotanus Cuatrec identified limonene and safrole [12], identified in the Croton campestres A. St. Hils. cariofeno oxide and 2 humulene oxide as the major compounds [19], studying Croton gossypiifolius Vahl identified the $\alpha$-cedrene oxide espetuleno, valencene, $\alpha$-cadinol,

Table 2: Mean values of $R$. (Boophilus) microplus reproductive parameters, engorged and subjected to treatment with different botanical extract's concentrations of C. blanchetianus leaves

\begin{tabular}{|c|c|c|c|c|c|c|c|}
\hline Treatments/concentration & PPP (days) & PP (days) & IPO (\%) & $\operatorname{IER}(\%)$ & IEP (\%) & IF (g) & Mortality (\%) \\
\hline $\mathrm{G} 1-2 \%$ & $3.0 \pm 0.5^{\mathrm{a}}$ & $10.3 \pm 1.5^{\mathrm{a}}$ & $89.3^{1}$ & 59.7 & 45.9 & 0.11 & 66.7 \\
\hline $\mathrm{G} 2-1 \%$ & $1.9 \pm 0.7^{\mathrm{b}}$ & $12.1 \pm 1.8^{\mathrm{a}}$ & $63.3^{1}$ & 47.9 & 38.7 & 0.37 & 12.1 \\
\hline G3-0.4\% & $1.7 \pm 1.2^{\mathrm{b}}$ & $9.2 \pm 2$ & $19.5^{2}$ & 38.6 & 31.6 & 0.13 & 60.6 \\
\hline CG-distilled water & $1.5 \pm 0.2^{\mathrm{b}}$ & $12.5 \pm 2.5$ & $66.7^{1}$ & 72.6 & 0.0 & 0.33 & 20 \\
\hline
\end{tabular}

Mean values with different letters per line and numbers per column differ significantly ( $\mathrm{P}<0.05)$ : Pre-laying period; PP: Laying period; IPO: Egg production rate; IER: Reproductive efficiency rate; IEP: Efficacy rate of the plant; IF: Fertility rate) C. blanchetianus: Croton blanchetianus, R. (Boophilus) microplus: Rhipicephalus (Boophilus) microplus 
germacrene-D, longifoleno and pentolato of geranila [20], studying C. blanchetianus identified chemical components 36, among them, a-pinene, p-mentha-1,3,8-triene, oxygenated sesquiterpenes hydrocarbons. This variety of chemical compounds together with the ethno pharmacological knowledge, especially popular knowledge obtained in the Brazil's semiarid region, has encouraged us to test the Croton's essential oil in bioassays against cattle tick.

\section{CONCLUSIONS}

The leaves of Croton have a good yield of essential oils, which facilitate chemical and formatting bioassays. There is a varied chemical composition suggesting that Croton oil is a good prospect for pharmacological studies. Biological action data indicated that it promoted good therapeutic action represented by the final mortality rate of the tick and Croton oil interferes with the life cycle of beef tick without developing a systemic toxic activity. This result has good prospects for alternatives control in reducing toxic wastes both in the animal undergoing treatment and the environment.

\section{ACKNOWLEDGMENT}

This work was accomplished with support from the National Council of Scientific and Technological Development (CNPq), Federal University of Campina Grande-PB (UFCG), and the Regional University of Cariri - Ceará State (URCA).

\section{REFERENCES}

1. Agnolin CA, Olivo CJ, Leal ML, Beck RC, Meinerz GR, Parra CL, et al. Efficacy of citronella [Cymbopogon nardus (L.) Rendle] oil in the control of bovine ectoparasites. Rev Bras Plantas Med 2010;12: 482-7.

2. Álvarez V. Control in vitro de carrapatas (Boophilus microplus; Acari: Ixodidae) mediante extractos vegetales. Rev Biol Trop 2008;1:291-302. [Article in Portuguese].

3. Barbosa CS, Borges LM, Nicácio J, Alves RD, Miguita $\mathrm{CH}$, Violante IM, et al. In vitro activities of plant extracts from the Brazilian cerrado and Pantanal against Rhipicephalus (Boophilus) microplus (Acari: Ixodidae). Exp Appl Acar 2013;60:431-43.

4. Chaceiro AA, Alencar JW, Matos JF, Machado MI. The essencial oil of Croton adenocalyx A. DC. A. J Essent Oil Res 1980;2:145-6.

5. Babile EL, Fourast FI, Mouli C, Bessiere JM, Roques C, Haddioui L. Essencial oil of leaves of Croton campestris ST. Hilaire. Its secretory elements, and biological activity. J Essent Oil Res 2009;21:272-5.

6. Drummond RO, Ernst SE, Trevino JL, Gladney WJ, Graham OH. Boophilus annulatus and Boophilus microplus: Laboratory tests for insecticides. J Econ Entomol 1973;66:130-3.

7. Gomes AP. Revisão das espécies sulamericanas de Croton L. Subgen. Croton sect. Argyroglossum Baill. (Crotonoideae- Euphorbiaceae). Brasil: Tese de Doutorado. Universidade Federal Rural de
Pernambuco, Recife-PE; 2006. p. 124

8. Lima SG, Citol AM, Lopesa JA, Neto JM, Chaves MH, Silveira ER. Fixed and volatile constituintes of genus Croton plants: Croton adenocalyx Baill. Euphorbiaceae. Rev Latinoam Química 2010;38:133-44.

9. Matos FJ. Introdução à Fitoquímica Experimental. $2^{\text {nd }}$ ed. Fortaleza: Edições UFC; 1997. p. 126.

10. Maciel MA, Pinto AC, Veiga VE. Plantas medicinais: A necessidade de estudos multidisciplinares. Química Nova 2002;23:429-38.

11. Nunes-Arévalo LA, Moreno-Murino BA, Quijano-Celis CE, Pino JÁ. Composition of the essencial oil from lives of Croton bogotanus Cruatec, grown in Colombia. J Essent Oil Res 2010;22:486-7.

12. Oliveira RN, Dias IJ, Câmara CA. Estudo comparative de óleo essencial de Eugenia punicifolia (HBK) DC. De diferentes localidades de Pernambuco. Rev Bras Farmacogn 2005;15:39-43.

13. Santana VS. Estudo Comparativo de Óleos Essenciais de Espécies de Croton do estado de Sergipe. (Dissertação Apresentada ao Núcleo de Pós-graduação de Química - Mestrado em Química). Universidade Federal de Sergipe-SE; 2001.

14. Santos EA, Carvalho CM, Costa AL, Conceição AS, Moura FB, Santana AE. Bioactivity Evaluation of Plant Extracts Used in Indigenous Medicine against the Snail, Biomphalariaglabrata, and the Larvae of Aedes aegypti. Evid Based Complement Alternat Med 2012;20:1-9.

15. Silva JG, Lima GF, Paz LG, Matos MM, Barreto MF. Utilização de cactáceas nativas associadas à silagem de sorgo na alimentação de bovinos. Rev Científica Produção Anim 2010;1:1-9. [Article in Portuguese].

16. Suarez AI, Oropeza M, Vasquez L, Tilett S, Compagnone RS. Chemical composition of essencial oil of Croton gossypiifolium from Venezuela. Nat Prod Com 2011;6:97-8.

17. Terassani E, Santos HD, Silva ID, Cardoso BK, Sousa SG, Gazin GC. Efeito do extrato de Azadirachta indica em carrapatos. Arq Ciências Vet Zool UNIPAR 2012;15:197-200.

18. Sindhu ZU, Jonsson NN, Iqbal Z. Syringe test (modified larval immersion test): A new bioassay fortesting acaricidal activity of plant extracts against Rhipicephalus microplus. Vet Parasitol 2012;188:362-7.

19. Silva CG, Zago HB, Junior HJ, Da Camara C, Oliveira JV, Barros R, et al. Composition and chemical activity essencial oil of Croton grewloides Baill. Against Mexican bean weevil (Zabrotes subfasciatus Boheman). J Essent Oil Res 2008;20:179-82.

20. Hakaru U. Manual para diagnóstico das parasitoses em ruminantes. $4^{\text {th }}$ ed. Brasil: Salvador; 2012. p. 144.

\footnotetext{
How to cite this article:

Rodrigues OG, Falcão BRM, Barbosa BC. In vitro biological activity

of the Croton blanchetianus (Baill) essential oil against Rhipicephalus

(Boophilus) microplus (Acari: Ixodidae). J App Biol Biotech.

2019;7(02):55-58. DOI: 10.7324/JABB.2019.70210
} 